\title{
Erken Çocukluk Döneminde Anaokulu ve Anasınıflarında İki Dilli Eğitim Uygulamaları ve Deneyimleri Üzerine Öğretmen Görüşleri
}

\section{Teachers' Opinions Concerning Bilingual Education in Early Childhood: Practice and Experience in Pre-School and Nursery Classes}

\section{Bengül Gülay ÇETINTAŞ* Zeliha YAZICI"**}

$\ddot{O}_{z}$ : Erken çocukluk döneminde ikinci dil eğitimi son ylllarda tüm dünyada olduğu gibi ülkemizde de giderek önem kazanmaktadır. Avrupa Birliği (AB), 3-dil formülü hedefine ulaşmak için ikinci dil eğitimini mümkün olduğunca erken yaşta ve hatta kreşlerde ve anaokullarında başlanmasını önermektedir. İkinci dil öğretimine yönelik politikalarının yanı sıra dilbilimcilerin ve eğitim bilimcilerin de ortaya koydukları araştırmalarda erken yaşta ikinci dil eğitimini desteklediği görülmektedir. Son yıllarda ülkemizde sayıları giderek artan iki dilli eğitim uygulamaları yapan kreşlerde ve anaokullarında "immersion yönteminin" giderek daha yaygın bir biçimde kullanıldığını görmekteyiz. Bu çalışmada; güncel araştırmalar 1şı̆̆ında ikinci dil ve iki dilli eğitim uygulayan anaokullarında uygulanan "immersion" diğer bir adıyla "daldırma yöntemi" ele alınıp, söz konusu yönteme yönelik uygulamalar ve deneyimler görevli öğretmenlerin görüşlerine başvurularak tespit edilmeye çalışılmışıır. Ayrıca uygulamalarda ortaya çıkan zorluklar ve sorunlarla ilgili olarak çözüm önerileri sunulmuştur.

Anahtar sözcükler: Yabanc1 Dil Öğretimi, Erken Yaşta Dil Öğretimi, Erken Yaşta Dil Öğretimi Yöntemleri, Daldırma Yöntemi ile Dil Öğretimi. Öğretmen Görüşleri

Abstract: As is the case worldwide, teaching a second language in early childhood is gradually gaining importance in Turkey. In order to attain the objective of 3 languages, the European Union (EU) recommends starting teaching the second language at an early age, even in preschool and nursery classes. In addition to policies regarding teaching a second language, linguists and teachers also corroborate the notion of teaching second language at an early age. It can be observed that the "immersion method" began to be used more frequently in recent years in preschools and nursery classes offering bilingual education. This study discusses the immersion method employed in those pre-schools offering bilingual and second language education, from actual studies, and determines the practices and experiences regarding this method through obtaining the opinions of the teachers in charge and, some solutions are suggested for the difficulties and problems experienced.

Keywords: Foreign Language Teaching, Language Learning at an Early Age, Methods for Learning Foreign Languages at an Early Age, Learning Foreign Language via the Immersion Method, Teachers' Opinions

\footnotetext{
* Doç. Dr., Akdeniz Üniversitesi, Edebiyat Fakültesi, Alman Dili ve Edebiyatı Bölümü, Antalya.

bengulcetintas@akdeniz.edu.tr

** Doç. Dr., Akdeniz Üniversitesi, Eğitim Fakültesi, İlköğretim Bölümü, Antalya. zyazici@akdeniz.edu.tr
} 


\section{Giriş}

Yaşam boyu gelişimde sosyal, duygusal, dil ve bilişsel gelişime yönelik en hızlı değişimler erken çocukluk yıllarında gerçekleştiği için gelişimsel olarak bu dönem kritik dönem olarak kabul edilmektedir. Çocuklar yaşamın bu evresinde dünyayı anlamlaştırmasına yarayan bilgileri edinmekte, edindiği bilgileri belleğe depolama, yeni bilgilerle var olan bilgileri yorumlayarak yeniden düzenleme ve eleştirel düşünme gibi zihinsel süreçlerini şekillendirmektedir. Erken yıllarda çocuğun zihinsel süreçlerini yapılandırmasında biyolojik olarak sahip olduğu potansiyeli ortaya çıkarmasında en önemli çevresel faktörler aile, okul ve akran gibi sosyal yapılardır. Sosyal bir varlık olan çocuğun, doğuştan getirdiği dil ve düşünme kapasitesinin yapı iskelesi erken çocukluk yıllarındaki sosyal etkileşimleriyle edindiği deneyimler önemlidir. Aile çocuğa, doğumdan başlayarak yaşadığı dünyaya yönelik bilgileri, davranış şekillerini, inanç, öğreti ve kuralların oluşturduğu bir kültür yumağı sunmaktadır. Büyüme ve gelişme sürecindeki çocuk bu bağlamda edindiği deneyimleriyle dil ve düşünme becerisini şekillendirmektedir (Adalı 1998).

Dil ve düşünme becerisi açısından çocuğun dış uyaranlara en açık olduğu, davranış değiştirme kapasitesinin çok yüksek ve zihinsel uyum açısından da en esnek olduğu bu yıllar, tüm gelişim alanlarının merkezi olan beyin gelişimi açısından da son derece kritiktir (Barrett 2014). Özellikle yaşamın ilk iki yılı beyin gelişiminin en dinamik olduğu yıllardır (Chugani 1999). Turan ve Özbay'ın (2016) aktarımına göre 1-2 yaş arasında beyin yarım küreleri arası bağlantıların artışıyla birlikte görsel-uzaysal ve görsel-duyusal-motor becerilerin gelişmesi, 2-12 yaşlar arasında ise konuşma alanlarında belirgin dendritik dallanmaların oluşumu söz konusudur.

Snaptik bağların daha çok erken çocukluk yıllarında gerçekleştirildiğini vurgulayan beyin ve sinir sistemi araştırma sonuçlarında özellikle beyninde fiziksel koordinasyon, algı, dikkat, bellek, dil işlevleri, mantıklı düşünme ve hayal gücü ile ilgili bölgelerin erken dönemde geliştiğini vurgulanmaktadır (Stiles 2000; Ram-Tsur et al. 2013). Bu araştırma sonuçları tüm gelişmiş ülkelerde olduğu gibi ülkemizde de erken çocukluk eğitiminde yeniden yapılanmayı gündeme getirmiştir. Erken çocukluk eğitim programlarına çocukların dil ve düşünce gelişiminde de en kritik süreç erken çocukluk yıllarının olduğu düşüncesinden hareketle ülkemizde de birçok anaokulunda iki dilli erken çocukluk eğitim programları uygulanmaya başlamıştır.

Ülkemizde, 15 yılı aşkın sürenden beri, $\mathrm{AB}$ dil politikalarına paralel olarak erken yaşta yabancı dil eğitimi ve öğretimi ve çok dillilik vazgeçilmez hedef olarak kabul edilmektedir. Ancak Türkiye'de erken yaşta ikinci dil denildiğinde ilkokulun ilk sınıflarından çok, okul öncesi eğitim ve öğretim kurumlarında sunulan ikinci dil dersleri anlaşılmaktadır. Son yıllarda sayıları binleri aşan okul öncesi eğitim kurumları sundukları eğitim programlarılla ikinci dil eğitimi konusunda birbirleriyle kıyasıya rekabet etmektedirler. İkinci dil eğitim politikalarının yanı sıra dilbilimcilerin ve eğitim bilimcilerin ortaya koyduğu araştırmalar da ikinci dil eğitiminin erken yaşlarda desteklenmeye başlanması gerektiği vurgulanmaktadır. Dilbilimsel ve sinir-bilimsel araştırma sonuçları ile beyin araştırmalarından elde edilen bulgularda çocukların dil edinim belleğinin tek bir dille sınırlı olmadığını, aksine birden fazla dil öğrenecek bir potansiyele sahip olduklarını göstermektedir. Özellikle erken çocukluk yılları, dil ediniminde en duyarlı dönem olarak ifade edilmektedir. Franceschini, iki dilin paralel olarak erken yaşlarda edinilmesinin, sonradan öğrenilecek yeni diller için bağlantı noktaları oluşturduğunu vurgulamaktadır. Özellikle her yeni öğrenilen dil Broca alanındaki ağ sistemine entegre olduğu düşüncesinden hareketle, dilsel ağların (network) erken yıllarda tesis edilmesinin işlevsel olduğu savunmaktadır (Franceschini 2002, 59). De Bleser (2006) da erken çocukluk döneminde ikinci bir dili edinen çocukların beyinlerinde anadil ile aynı alanların aktif hale geldiğini vurgulamaktadır. $\mathrm{Bu}$ da, erken çocukluk çağında beynin anadil ve ikinci dil edinim sürecindeki işleyiş biçiminin aynı 
olduğu anlamına gelmektedir. Örneklerden de anlaşılacağı üzere çocuklar, beyin fonksiyonlarının en yoğun olduğu erken çocukluk yıllarında eğer ikinci bir dile doğal etkileşimler yoluyla maruz kalırlarsa ikinci dili de neredeyse anadili kadar iyi öğrenebilirler.

Çocukluk döneminde beyindeki dil edinim penceresi daha aktif olduğu için çocuklar anadil becerilerini oluştururlarken ikinci dili de anadilleri gibi doğal yollarla edindikleri için ikinci dili edinmesi yetişkinlerden daha kolaydır (Chilla \& Fox-Boyer 2012). Bu nedenle gelişim psikolojisi açısından da erken çocukluk dönemi iki ya da çok dilin edinilmesinde de kritik dönem sayılmaktadır (Doyé 2009). Krashen (1973)'da erken yaşlarda ikinci dili edinme olanağına sahip olan çocukların ikinci dili de anadili gibi rahatlıkla öğrenebildiğini savunmaktadır.

Erken yaşta iki dilli eğitim programlarıyla ilgili yapılan güncel araştırmalarda, ikinci dil öğretiminin çocuğa birçok katkısının olduğu savunulmaktadır. Özellikle Kritik Dönem Hipotezi'ni temel olan araştırmalarda iki dilli eğitim programlarının çocuğun dil ve bilişsel gelişimine olumlu katkıları olduğu belirtilmektedir. Bu araştırmalarda genel olarak erken çocukluk yıllarının yalnızca anadilde değil ikinci dilde de kritik dönem olduğu vurgulanmakta ve anadil öğrenme süreçleriyle ikinci dili öğrenme süreçlerinin benzer olduğu ifade edilmektedir. Ayrıca çocukların dil eğitiminde iki dilli erken çocukluk eğitim programlarının tek dilli eğitim programlarından daha başarılı olduğuna da dikkat çekilmektedir (Barnett et al. 2007; Schwartz, MorSommerfeld \& Leikin 2010; Schwartz et al. 2015; Schwartz \& Palviainen 2016; Tekin 2016).

Gündoğar (2004), erken çocuklukta ikinci dili öğrenen çocukların, iki dilin, ses, sözcük ve cümlelerin benzerlik ve farklılıkları konusunda karşılaştırma yaparak farklı dillerin farklı kuralları olduğu konusunda bir dil bilinci geliştirildiğini savunmaktadır. Bleyhl (2000), yaptığ1 çalışmada çocukların ikinci dil eğitimi alan çocukların ikinci yılın sonunda hem aksansız bir şekilde ikinci dili kullanmaya başladıklarını hem de bağımsız olarak belli dil yapılarını kullanabilme konusunda başarı gösterdiklerini belirlemiştir. Araştırmacı bu bulgudan hareketle erken yaşta ikinci dilin edinilmesinin, çocuklarda ikinci dilde konuşma becerisinin gelişmesinin kendini ifade etmede olumlu katkılar sağladığını vurgulamıştır.

Doyé (2009), erken yaşta başlayan ikinci dil eğitimi çocuğun toplumsal ve bireysel gelişimini etkilediği gibi kültürel gelişimine de olumlu yönde katkı sağladığını, özellikle çocuğun kendi dili ve kültürünün dışında başka dillerin ve kültürlere karşı farkındalık kazanacağını ifade etmektedir. Ayrıca, kültürlerarası iletişim yetisinin kazanılmasına temel oluşturularak çocukların farklı kültürlerden insanlara da olumlu yaklaşım göstereceğini vurgulamaktadır. Genç'in (2007) aktarımına göre erken yaşta farklı bir dil ile karşılaşan çocuklar, kendi kültürel değerlerini ilerde yabancı ülkelerdeki kültürel değerlerle de karşılaştırarak daha hoş görülü, evrensel ve iletişim yetisi güçlü bir birey olacaktır.

Erken çocukluk yıllarında ikinci dil eğitimiyle ilgili görüşleri özetlemek gerekirse, anadilinden farklı bir dil edinen çocuk, hangi durumda hangi dili kullanması gerektiği konusunda duyarlılığa ulaşarak, ne zaman, kiminle hangi durumda, hangi dilde iletişim kurması gerektiğine karar vermesini sağlayarak düşünme becerilerini geliştirecektir. Özellikle sosyal iletişimlerinde bir dilden diğer dile geçmesi, konuşma dilini devamlı değiştirmesi düşünce esnekliği yaratacak ve bu da çocuğun hareket ve yaratıcılık yetisini artıracaktır.

İki dilli çocukların dil gelişimi ve dil eğitimlerinde kullanılan iki dilli eğitim modellerinin belirlenmesinde birçok sosyolojik faktörün etkili olduğu görülmektedir. Örneğin; iki dilli eğitim modelleri toplumlardaki azınlık-çoğunluk dil ilişkileri, dillerin prestij ve statüleri, etnik gruplar gibi birçok bağlamsal faktörlerden etkilenmektedir. Uluslararası arenadaki anaokullarında tercih edilen iki dilli eğitim modellerinin nasıl uygulanacağı belirli sosyo-kültürel, dilsel, sosyopolitik 
ve etnik bağlamlar daha etkili olmaktadır. Dil prestiji açısından bazı diller diğerlerinden daha değerli görülebilirken, örneğin İngilizce, azınlık dillerinin karşısında da eğitim dili daha değerli görülebilmektedir (Hickey 2001; De Palma 2010, Schwartz \& Palviainen 2016).

Her bir bağlam kendine özgü bir yapıya sahip benzersiz önekler taşıdığı için erken çocuklukta uygulanan iki dilli eğitim modellerini belli kategorilerde genelleştirmekte zorlaşmaktadır. Bu çalışmada iki dilli eğitim modeli olarak "iki yönlü dardırma modelinin" kullanıldığı anaokullarındaki uygulamalara yönelik öğretmen izlenimleri incelenmiştir.

\section{Erken Çocuklukta Daldırma Yöntemi Modeli}

Erken çocukluk yıllarında ikinci dil eğitim ve öğretimini destekleyen farklı yöntemler bulunmaktadır. Bu yöntemlerden en etkili ve başarılı kabul edilen "immersion" olarak bilinen daldırma modelidir. "Bir dile dalma" (İng. immerse) anlamına gelen bu modelde çocuğun tıpkı suya dalar gibi yeni bir dile dalması sağlanmaktadır. "Dil banyosu" olarak da tanımlanan bu model 1960-1970'lı y1llarda Kanada ve Amerika Birleşik Devletleri'nde geliştirilmiş olup (Cohen \& Swain 1976), günümüzde ülkemiz de dâhil olmak üzere birçok ülkede yaygın olarak kullanilmaktadır.

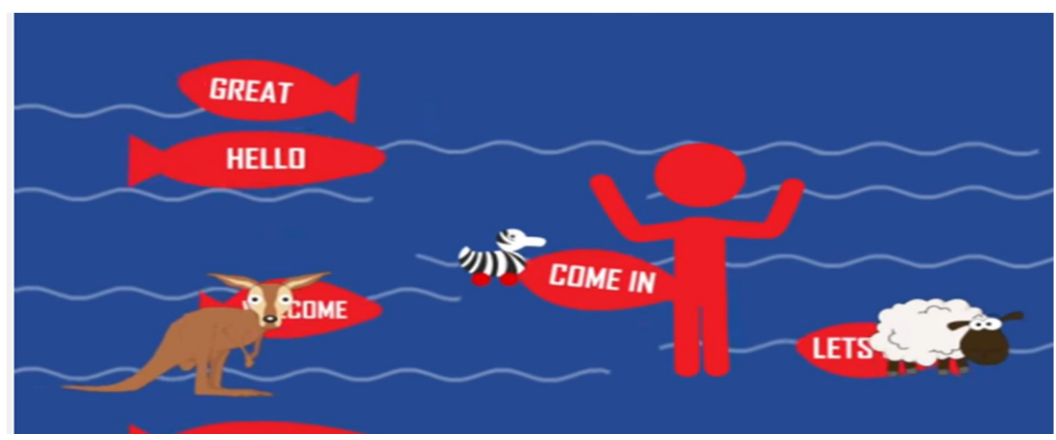

Kaynak: https://www.youtube.com/watch?v=56fBmoX6p7Q

Anaokullarında, anasınıflarında ve birinci ikinci sınıf kademelerinde uygulanan "erken immersion" (Carroll 2012, 5) programında öğrenilmesi istenilen ikinci dil, ana dil ile birlikte sınıf ortamlarında günlük dil olarak kullanılmaktadır. Immersion modelinde sınıf içi etkinlikler uygulanırken doğal ortamda oyun yoluyla çocuklar iki dile dalmaktadır. Çocuğun bu doğal ortamda anadiliyle birlikte ikinci dilde de dinleme ve anlama becerisi desteklenmektedir. Çocuk, ilk başlarda ikinci dildeki her sözcügü bilmek ve anlamak zorunda da değildir. Çocuk, dilin sözcük ve dilbilgisi kurallarını ezberlemeden tıpkı ana dili edindiği gibi doğal bir ortamda ve farkına varmadan edinmektedir. Immersion programında ikinci dil bir derse konu değildir, dilbilgisi açıklamaları ve alıştırmaları yapılmaz ve çocuğun ders ortamında konuşurken yaptığı dilsel hatalar da öğretmen tarafından düzeltilmez. Bu modelde öğretmenler eğitim etkinliklerini ve günlük rutinlerini yaparken her söylediğini jest, mimik ve beden hareketleriyle birlikte görsel materyalleri de yoğun olarak kullandığı için çocuğun ikinci dili edinmesinde birden fazla duyu harekete geçirilmektedir. Örneğin; "ben sandalyeye oturuyorum" ifadesi aynı zamanda "sandalyeye oturma" eylemiyle birlikte ifade edilir. $\mathrm{Bu}$ durum çocuğun sözel ifadelerin anlamsal boyutunda zihinsel şemalar oluşturmasına zemin hazırlamakta ve dolayısıyla çocuk için dil günlük yaşamın doğal bir parçası olarak hayatına dâhil edilmektedir (bk. http://www.fmksonline.de/; Wode 2004).

Erken çocukluk döneminde çocuklar anadilini ses yapısı, anlamsal, içerik ve kapsamını anne babalarıyla etkileşimlerinde maruz kalarak doğal yolla edindiği gibi ikinci dilin temel yapı taşlarını da ikinci dilin kullanıldığı ortamlara doğal yolla maruz kalarak gerçekleştirmektedir (Yazıcı 2013). 
Beyin araştırma sonuçlarında, beyindeki dil edinim penceresinin yaşamın 3-8 yaş arasında daha aktif olduğu belirlenmiştir (Chilla \& Fox-Boyer 2012). Bu nedenle bu zaman aralığından ilk dil gibi ikinci dil ediniminde de beyindeki dil edinim penceresinin aktif zaman dilimidir. Erken çocukluk döneminde uygulanan immersion modelin de bu bilimsel bilgi 1şı̆̆ında dört temel ilkesi bulunmaktadır. Bunlar;

a) Sınıf ortamında anadili ile öğretilecek yabancı dil eş zamanlı olarak kullanılır (öğretilecek olan yabancı dil sınıf ortamında en az ana dil kadar ve sürekli olarak kullanılır).

b) Yabancı dilin öğretilmesinde "bir dil - bir ögretmen" ilkesi uygulanmaktadır. Öğretmenler eş zamanlı olarak sınıf ortamında etkinliklerini uygulamakta ve gün içerisinde çocuklarla her iki öğretmen kendi hedef dilini kullanarak çocuklarla etkileşim kurmaktadır.

c) Yabancı dil öğretmenleri öğretecekleri dilin doğal konuşucusu (native speaker) ya da doğal konuşucu seviyesine sahip olmalıdır.

d) Yabancı dil öğretmenleri, anadil öğretmenleriyle birlikte sürekli olarak sınıf ortamında bulunmalıdır (Wode 2007; Verein FMKS, http://www.fmks-online.de/).

Sınıf ortamında yabancı dilin en az ana dil kadar kullanılması ve yeni dile eşit süre yer verilmesi immersion yönteminin en önemli ilkelerindendir. Immersion yöntemine göre çalş̧an anaokullarında hedef dilin öğretilmesi yabancı dil dersi saatleri ile sınırlı değildir. Öğrenilmesi istenilen yabancı dil sınıf ortamında sürekli olarak ve birçok bağlamda kullanılmaktadır. Örneğin kahvaltı, temizlik vb. rutin etkinlikler yapılırken, oyun oynama, müzik, sanat, bilim, matematik, doğa gezileri, öykü etkinliklerinin hepsinde kullanılmaktadır. Yabancı dile, çocuğun yaşına uygun bir biçimde günlük yaşantı içinde sürekli olarak yer verilmesi, çocukların bu yeni dili doğal olarak ve farkına varmadan edinmelerine olanak sağlamaktadır. Yabancı dil doğal ortamın bir parçası olarak sınıf ortamına yansıtıldığında çocuklar dil öğrenme kaygısından uzaklaştırılarak kendilerini baskı altında hissetmeden tıpkı ana dillerini öğrendikleri gibi ikinci bir dili de rahatlıkla öğrenebilmektedir.

Immersion yönteminin diğer bir vazgeçilmez ilkesi ise "bir ögretmen-bir dil" ilkesidir. $\mathrm{Bu}$ ilke, immersion sistemini uygulayan anaokullarındaki sınıf ortamlarında sürekli olarak iki görevli öğretmenin bulunduğunu ifade etmektedir. Ana dilden sorumlu eğitimci çocuklarla anadilinde konuşurken, diğer öğretmen yabancı dilin öğretimi ile ilgili uygulamaları yürütüp çocuklarla sadece yabancı dilde iletişime geçmektedir. Bu sistemin işleyiş̧ine göre her iki öğretmen sınıf ortamını paylaşarak sorumlu oldukları dili kullanmaktadırlar (bk. Kersten 2009). Bu model farklı dilleri konuşan ebeveynleri anımsatmaktadır, hem anne hem de baba aile içinde çocukla konuşurken kendi anadillerini kullanmaktadırlar. Ancak yöntemin başarıya ulaşabilmesi için yabancı dilin öğretimini üstlenen öğretmenin bu dili ana dil olarak veya ana dile yakın bir seviyede konuşması son derece önemlidir. Bu yöntem ile yabancı dil öğretmeninden dil öğretiminin yanında çocuklara hedef dilin konuşulduğu ülkenin kültürü hakkında yeterince bilgi aktarması da beklenmektedir. Bundan dolayı yabancı dil öğretmeninin yurt dışı deneyimi olması önemli rol oynamaktadır.

Immersion modelinin kullanıldığı eğitim kurumlarında, yabancı dil öğretmenin gün boyu ana dil öğretmeni ile birlikte sınıf ortamında bulunması ve öğretimi yönlendirmesi önkoşul olarak görülmektedir. Geleneksel yabancı dil öğretiminde dersler belli saatlerle sınırlı olarak yürütülmektedir ve öğretmen bu saatlerin dışında sınıf ortamından uzaklaşmaktadır. Immersion modelini geleneksel yöntemden güçlü kılan yönü, yabancı dil öğretmenin gün boyu sınıf içinde bulunarak, öğretilecek olan yabancı dilin farklı bağlamlarda ve doğal durumlarda kullanılmasıdır. Immersion modelini uygulayan eğitim kurumlarında aynı sınıfı paylaşan iki öğretmenin de 
erken çocukluk eğitimi konusunda da pedagojik bilgiye sahip olması gerekmektedir.

Anaokullarında ve anasınıflarında başarılı iki dilli bir eğitimin öncelikle görevli öğretmenlerin yeterlilikleriyle ilgilidir. Eş öğretmenlerinin farklı programlardan mezun olması, birlikte çalışmaları, sınıf ortamına deneyimlerini aktarmaları, öğretim sürecini verimli hale getirmektedir. Ancak eş öğretmenlerin uyumlu çalışmaması halinde bu durumun bazı pedagojik sıkıntıları beraberinde getirmesi kaçınılmazdır.

\section{Yöntem}

Bu çalışmada, nitel araştırma yönteminden faydalanılmıştır. Veriler, araştırmacı ile araştırmanın öznesi konumunda yer alan kişi/kişiler arasında geçen kontrollü ve amaçlı sözel iletişim biçimi olan görüşme tekniği kullanılarak elde edilmiştir. Görüşmenin sürdürülmesi, daha sistematik ve karşılaştırılabilir bilgi toplamak (Yıldırım \& Simsek 1999) için iki dilli eğitim uygulamaları hakkında önceden yarı yapılandırılmış bir soru havuzu hazırlamıştır. Hazırlanan yarı yapılandırılmış sorularla iki yabancı dil öğretmeni, okul öncesi öğretmeni olmak üzere toplam dört anaokulu öğretmeniyle görüşme yapılmıştır.

Katılımcılar; Tüm katılımcılar immersion modeliyle Türkçe-İngilizce iki dilli okul öncesi eğitim programı uygulayan anaokullarında görev yapmaktadır. Gönüllü olarak görüşmeyi kabul eden İngilizce öğretmenlerinden (A1) birinin anadili Türkçe olup, İngilizce öğretmenliği alanından mezundur. İngilizce öğretmenlerinden ikincisi (A2) ise anadili İngilizce olup, ikinci dili Türkçedir. Türkçe eğitimi veren öğretmenlerin her ikisinin (A3 ve A4) de anadili Türkçe olup, İngilizce seviyesi yalnızca anlama seviyesindedir. Her dört öğretmen Türkçe-İngilizce iki dilli anaokullarında 3 yıldır görev yapmaktadır. Dolayısıyla erken çocukluk döneminde immersion modeliyle iki dilli program deneyimine sahip olduklarından iki dilli eğitim uygulamalarında uzman olarak kabul edilebilir varsayılmıştır.

Tüm katılımcılar farklı zaman dilimlerinde 3-6 yaş arasında çocuklarla aktif çalışma deneyime sahiplerdir. Ayrıca, okul öncesi eğitimde dil odaklı müfredat hazırlama ve sınıf içi uygulamalarda karar verme süreçlerine aktif olarak katılmaktadırlar.

Verilerin toplanması; Yarı yapılandırılmış görüşme için hazırlanan sorular aracıllı̆̆ıla öğretmenlerin iki dilli programlardaki eğitimsel deneyimleri, program uygulamalarında karşılaştıkları, benzerlikler, farklılıklar ya da zorluklara yönelik düşünceleri alınmıştır. Öğretmenlerle görüşmeler yapılmadan önce araştırmacı tarafindan sınıf ortamı haftada bir gün tüm etkinliklerde (oyun, müzik, erken okuryazarlık becerileri, kahvalt1, yemek, masal gibi etkinlikler) 3 ay süreyle gözlem yapılmıştır. Daha sonra okul ortamında öğretmenlerin her biriyle yaklaşık bir saat süreyle görüşme yapılmıştır. Tüm görüşmeler ses kaydediciye kaydedilmiş ve daha sonra yazılı metne aktarılmıştır. Tüm görüşmeler tamamlandıktan sonra araştırmacılar tarafindan transkripsiyonu yapılmıştır. Görüşme verilerinin analizinde tematik analiz (Braun \& Clarke 2006) uygulanmıştır. Öğretmenlerin iki dilli eğitim uygulamalarına bakışı, uygulamada ortaya çıkan sorunlar ve zorluklar, uygulamaları arasındaki farklılıklar şeklinde temalar ve alt temalar halinde organize edilmiştir.

\section{Bulgular ve Yorum}

$\mathrm{Bu}$ bölümde, öğretmenlerin yansımalarından ortaya çıkan üç temel tema tartışılmıştır:

(1) Erken çocukluk döneminde iki dilli programa bakış, bilgi ve genel deneyimler;

(2) Immersion modeline yönelik yaklaşımlar ve uygulamalar;

(3) İki dilli programlar gerçekleştirilirken ortaya çıkan zorluklar ve sorunlar. 


\section{Erken Çocukluk Döneminde İki Dilli Programa Bakış, Bilgi ve Genel Deneyimler}

Öğretmenlerin erken çocuklukta immersion modeliyle uygulanan iki dilli eğitimin uzun vadeli perspektiflerine bakıldığında, dört öğretmenin belirttiği ortak tema, yabancı dil öğretimine erken başlanması gerektiği düşüncesidir. Ayrıca, dil öğretiminde doğru yöntemlerin kullanılması, çocuklarda dil kazanımının sürece bağlı etkilerinin fark edilmiş olmasıdır. Öğretmenlerin hepsinin ifadelerinde, süreç ilerledikçe çocukların yabancı dile karşı olumlu tutum sergiledikleri, İngilizceyi anlama ya da konuşma gibi dilsel yapılarında sürekli değişikliklerin olduğunu fark ettikleri görülmektedir. Ayrıca iki dilli eğitimin hem çocuklara hem de kendilerine yararları olduğunu düşündükleri görülmektedir.

A1 (İngilizce Öğretmeni):

Ĕ̆er program doğru uygulanırsa çok iyi sonuçlar doğurabilecĕgini düşünüyorum. 3 ylldır bu programda görev aldiğım süre içerisinde çocukların erken dönemden itibaren ikinci dile karşı ilgilerinin olduğunu ve farklı bir dilde şark söyleme, oyun oynama gibi etkinliklerde keyif aldıklarına şahit oldum. İngilizce ile ilk karşılaştıklarında ilgisizmiş gibi davranan çocukların özellikle şarkı ve dans gibi etkinliklere fiziksel tepkilerle eşlik ettiklerini fark ettim. Aslında farklı bir dille karşılaştıklarında o dili de bir oyun gibi düşünüyorlar sanırım. Tabi emin değilim bu konuda ama ben daha çok oyun ve müzikle etkinlikleri yaptığım için etkinlikleri ben devraldiğımda "yaşasın oyun oynayacă̆ız" gibi söylemleri çoğu zaman görebiliyorum. Tabi her çocuk için geçerli değil bu. Bazı çocuklar da etkinliğe ilk girişte çekimser kalyyorlar, sadece hareket varsa oyunda hareketlerle eşlik eden oluyor, bazı çocuklarda İngilizce etkinliklerinde yalnizca izleyici gibi davranabiliyor. Bu nedenle iki dilli eğitim programları uygulamalarında oyun, müzik gibi yöntemlerin kullanılması gerekli diye düşünüyorum.

Bazen çok komik durumlarla da karşılaşabiliyorum. Örneğin; "bana Türkçe ögretmeye çalışlyorlar". İkinci dilim Türkçe olduğu için aslında çocuklar benimle anadillerinde iletişime geçtiklerinde onlarla İngilizce iletişime geçsem de çocuklar kendisini anladığımın farkına vartyorlar. Özellikle 5-6 yaş gruplarında bunu görebiliyorum. Bazen benim Türkçe bilip bilmediğimi denemeye çalışan (ben böyle düşünüyorum, aslında niyetlerini tam bilmiyorum ama) çocuklarda oluyor. Örneğin, "teacher bu kalem, sen de söyle bu ka-lemmm" gibi ifadeleri duymak da ĕglenceli oluyor. Ingilizce şarkıları ögrenmekten inanılmaz zevk alıyorlar. Bazen onlar da bana Türkçe şarkllar ögretiyorlar. Bende onlardan ögreniyormuş gibi davrandığımda çok mutlu oluyorlar. Bir keresinde bir çocuk annesiyle konuşurken büyük bir heyecanla "annecim biz bugün teacher'a Türkçe şarkı öğrettik biliyor musun?" dediğini duydum. Bende veliye Ingilizce olarak evet "Bana Türkçe Şarkı ögrettiler” yanıtını verdiğimde çocuk çok mutlu oldu. Bunlarda aslında iki dilli çocuklarla yaşadiğım inanılmaz hoş duygular.

A2 (İngilizce Öğretmeni):

Doğru uygulanırsa çok iyi sonuçlar doğurabileceğini düşünüyorum. Çocukların ikinci dili ana dilleri gibi benimseyip konuşmaya çalıştıklarını ve konuşabildiklerini gördüm. Sene sonunda çocuklarımızın kendilerini ikinci bir dille ifade edebildiklerini ve ihtiyaçlarını ikinci dille ifade 
ederek iletişim kurduklarına şahit oldum

A3 (Türkçe öğretmeni):

İki dilli eğitimi erken yaşlarda düzenli almış çocukların (öğretmenin ifade ettiği bu çocuklar 5 yaşından beri immersion modeliyle İngilizce eğitimi alan çocuklardır) 6 yaşında dili anlama ve kendilerini Türkçe ve İngilizce ifade etmede daha aktif ve özgüvenli olduklarını, bilişsel açıdan da hızlı düşünme, ayrıntıları fark etme, bağıntı kurma becerilerinin artığın düşünüyorum. Farklılıklara saygı ve anlayış gelişimi de destekleniyor.

A4 (Türkçe öğretmeni):

Aslında önce kendimle ilgili çok şey kazandiğımı düşünüyorum. Ben 10 yıldır anaokulu ögretmeni olarak kreşlerde çalışıyorum. İki dilli okuldaki deneyim de 3 yllım olacak. Ben Türkçe ögretmeniyim yani anaokulu öğretmeniyim de görevim tüm etkinlikleri Türkçe yürütmek. İkinci dili bilmiyorum. Bir öğretmen olarak İki dilli eğitim veren bir okulda görev almak benimde kendimi geliştirmeni sağlad. Daha önce İngilizce anlamazken şimdi basitte olsa bende Ingilizce anllyorum ve ara ara konuşuyorum. Bu çok gurur verici benim için. Ayrıca geçen yll iki dilli eğitim veren bu okulda hem ögrretmen hem de veli olarak daha farklı duygular yaşadım. Size bir anne olarak çocuğumda yaşadığım tecrübelerle söylemek isterim. İnanın çok gurur verici bir durum bu. Kızım farkl bir yerde yani toplumda olduğumuz zaman anne olarakçok beğeniyorum kızımın başka bir dili anllyor olasından ve bazen insanlar nerde ögrendi, hangi okula gidiyor diye soruyorlardl bende gururlanıyordum. Ben düşünüyorum ki çocuklar erkenden başka bir dili öğrenince daha kolay oluyor. Bence olmall.

Erken yıllarda çocukların dille oynama, kendine özgü yollarla dil yaratma, yansıtma ve birden fazla dili doğal yollarla öğrenme eğilimleri vardır. Dolayısı ile çocuklar yeni bir dili kavramada yeteneklidirler. Dillerin yapısına göre fonoloji, ritim, vurgu, tonlama ve konuşma biçimini daha kolay kazanabilmektedirler. Erken çocukluk döneminde çocuklar merak ve öğrenme güdüsünün fazla oluşundan, gırtlak yapısının müsait olmasında, beyin gelişiminin hassas olmasından dolayı dil öğrenmeye daha açıktırlar. Dil edinimine daha yatkın oluşları ayrıca bu yaşta hata yapma kaygısının olmaması ve ikinci dili anadili gibi doğal yolla öğrenebileceği gibi nedenlerle yabancı dil eğitiminin erken yıllarda verilmesinin çocuklara yarar sağladığı düşünülebilir.

\section{Immersion Modeline Yönelik Yaklaşımlar ve Uygulamalar}

Immersion modelinde iki dilin eş zamanlı olarak sınıf ortamında kullanılması temel ilkelerden biridir. Erken çocuklukta iki dilli eğitim programlarında iki dilin eş zamanlı olarak verilmesi çocukların hem anadillerinde hem de ikinci dilde kendilerini ifade edebilmesine firsat tanımaktadır. Öğretmenlerin ifadelerinden sınıf ortamında iki dilin aynı anda kullanılması çocukların kendilerini en iyi konuştukları dilde ifade etmelerine olanak sağlamaktadır. Böylece çocuklara kendini ifade etmede sunulan esneklik, Duverger (2005)'a göre sınıf içerisinde her iki dili de bağlamsal olarak kullanma, bir dilde hedeflenen bir sözcük ya da kavramın edinilmesinde "mikro-dönüşüm" sağlamaktadır. Menken ve Garcia'nın (2010) belirttiği gibi, sınıf içi uygulamalarda iki farklı dilin kullanılması dil kullanımında çocuklara esneklik tanınması sınıfta etkin iletişim kurmayı sağlar. Anaokulu çağındaki çocukların yeni bir şey öğrenirken hata yapma konusunda düşünceleri yetişkinlerden farklıdır. Küçük çocuklarda yetişkinlerde olduğu gibi dil öğrenme endişesi ya da küçük düşme korkusu bulunmamaktadır. Ayrıca çocuklar yeni bir dil 
öğrenirken diğer insanların kendileri hakkındaki düşüncelerini önemsemezler. $\mathrm{Bu}$ da onların yeni bir dili daha kolay kabul etmelerine imkân sağlamaktadır (Lake \& Pappamihiel 2003; Küçükakın 2005). Dolayısı ile immersion modelinin kullanıldığı ortamlar stresten uzak ortamlardır. Çocuklar kaygı duymadan ihtiyaçlarını ya da iletişimlerini devam ettirebilirler. Bazen tek bir sözcükle, bazen bir hareketle bazen de iki dili birleştirerek etkileşimlerini devam ettirebilmektedirler. Önemli olan çocuklara sunulan zenginleştirilmiş dil çevresidir. Immersion modelinde de iki farklı dilde eş zamanlı olarak dil çevresi yaratıldığından çocuklar akranlarıyla ya da yetişkinlerle dili yaratıcı şekilde kullanım olanağı bulmaktadırlar. Öğretmenlerin ifadelerinde çocukların İngilizcede kendilerini ifade ederken çok yaratıcı yollar buldukları görülmektedir.

A1 (İngilizce Öğretmeni):

Sinıf ortamında günlük rutinlerde ve etkinliklerde Türkçe ögretmeniyle aktifliği eşit düzeyde paylaşmaya başliyoruz. Türkçe ögretmenin etkinliklerine daha aktif katılım gösterirken, benim uygulamalarımda yalnızca beni izliyorlar ve genelde sessizliği tercih ediyorlar. Ingilizce alt yapısı oluşana kadar genelde Türkçe ögretmenini tercih ediyorlar. Özellikle öz bakımlarında, bireysel ihtiyaçlarında bu durum daha da artıyor. Ancak zamanla Ingilizceyi anlamaya ve Ingilizce ögretmeninin kendilerini anladı̆̆ının farkına vardıklarında her iki öğretmenle de iletişim kuruyorlar. Sinıf ortamında çocukların iki dili birbirinden çok kolay ayırt ettiklerini gözlemliyorum. Sinıf ortamında yeni katılan bir çocuk bir hafta içerisinde her iki ögretmene de farkl hitap ediyor. Özellikle 4 yaş grubunda bunu görmek mümkündür. Örneğin, Bana hitap ederken "teacher", Türkçe ögretmenine hitap ederken "öğretmenin” şeklinde hitap ediyorlar. Çocuklar çalışırken her zaman farklı durumları görebiliyorsunuz. Örneğin; ben İngilizce bir soru sorduğumda ya da bir şey istediğimde bana Türkçe karşıllk veriyorlar. Ama birkaç basit sözcüğ̈̈ ögrendikten sonra (örneğin, good morning, have a nice day, thank you, please, give, go, put, come vb) benimle tek sözcükle bile olsa konuşmaya çalışıyorlar. Bazı zamanlar bana bir durumu anlatabilmek kullandiğı İngilizce sözcükle birlikte beden dillerini ya da işaretle göstererek anlatmaya çalıştıkları da oluyor. Bazen de özellikle İngilizce alt yapısı olan ve diğerlerine göre daha aktif kullanan bir çocuk, benim verdiğim yönerge ya da oyun kurallarını diğer akranlarına Türkçe olarak çeviri yaptığını görmekte mümkün oluyor. Özellikle bir oyun oynanırken, gruba yeni katılan bir arkadaşına "teacher şöyle diyor, bunu istiyor gibi oyunla ilgili bir kuralı anladığı kadarıyla arkadaşına Türkçe olarak aktaran çocukları da görmek mümkün. Bazen sinıf ortamında İngilizce sözcüklere Türkçeden aktarımlar yaptıklarını görmekte mümkün oluyor. Örneğin; "Teacher Ayşe go tuvalete" gibi bir cümle oluşturdukların görmekte mümkün. Aslında ikinci dilde çocukların bu şekilde cümleler ürettiğini duyduğumda çok mutlu oluyorum. Çünkü ikinci dili bir iletişim aracı olarak kabul ettiğini ya da cümle kurmaya yönelik gayret ettiğini düşünüyorum.

A4 (Türkçe Öğretmeni):

Genel okula ilk başladıklarında hele İngilizceleri olmadı̆̆ için çocuklar Türkçe kullanıyor ve Türkçe ögretmeniyle iletişim kurmayı tercih ediyor. Örneğin, su isterken, tuvalete gitmek için izin isterken. Ingilizce de tek sözcük kullanarak, ya da öğretmene işaret ederek, söylemek istediğini 
beden diliyle tarif ederek anlattkkları da oluyor.

\section{Immersion Modeline Yönelik Uygulamalar}

Erken çocukluk döneminde uygulanan immersion modeliyle yabancı dil öğretirken sınıf içi etkinliklerde kullanılan oyun, şarkı gibi etkinlikler çok önemlidir. Eğlenerek öğrenmek dili daha kolay kodlamaya olanak sunar. Bir dili öğrenmek ne kadar eğlenceli olursa çocuklarda o kadar çok etkinliğin içerisinde aktif olacaktır. Duygular öğrenmenin kapısıdır. Oyun sırasında öğrenme, duygusal bağlar oluşturduğu için de dil öğrenmenin en iyi yoludur (Dryden \& Vos 2005). Oyun çocuğun rahatlamasını sağladığ 1 için çocuğun stresten ve kaygıdan uzak bir ortamda öğrenmesini destekler (Fisher 2009). Dil öğretiminde müzik ve hareket çocuğun beden ve zihni eşgüdüm içerisinde kullanmasına olanak sunduğu için şarkı sözleriyle yabancı bir dili öğrenirken özellikle sözcük dağarcığını zenginleștirmesine yardımcı olur (Brewer \& Campbell 1991). Bu nedenle erken çocukluk eğitiminde bu tür etkinliklerin kullanımı son derece önemlidir. Öğretmenlerin ifadelerinde de çocukların bu etkinliklere keyifle katıldıklarına dair bilgilere rastlamaktadır.

A1 (İngilizce Öğretmeni):

Ingilizce ögretmeni olarak ben daha çok hareket, dans ve müzik ve müzikli oyun gibi etkinlikleri programında yoğun olarak kullanıyorum. Çocuklar bu etkinliklerde çok eğleniyorlar. İlk zamanlarda çocuklar İngilizceyi anlamasa da şarkllara ve hareketli oyunlara katılarak bir birleriyle etkileşime geçiyor. Türkçe öğretmeni ise oyun, masal, okuma yazma hazırlı gibi konularda daha aktif olabiliyor. Çocuklar Ingilizce anlama boyutunda belli bir noktaya geldiğinde ise masal, kurall oyunlar da programa dâhil etmeye başlıyorum.

A4 (Türkçe öğretmeni):

İlginçtir İngilizce şarkılar ögrenirken çocukların neredeyse hepsi katılıyor. Pek sorun yaşamıyoruz. İngilizce şarkılarla ve eğlenceli oyunlarla öğretilirken tüm çocuklar eğlenerek katıllyorlar. Tabi İngilizce şarkaları çok hareketli ve melodileri çok güzel, ögrretmende hareketlerle şarkiları ögrettiği için ben bile çok ĕgleniyorum.

\section{İki dilli programlar gerçekleştirilirken ortaya çıkan zorluklar ve sorunlar}

Erken çocukluk döneminde uygulanan immersion modeliyle yabancı dil öğretiminin başarıya ulaşması şüphesiz ki öğretmenlerin sahip olduğu mesleki yeterlikler ile doğru orantılıdır. Immersion yöntemi ile iki dili eğitim ve öğretim oldukça karmaşık bir süreçtir ve farklı beceri ve yeterliklerle donatılmış öğretmenlerin iş başında olmasını öngörmektedir. Doyé iki dilli okul öncesi kurumlarda çalışan öğretmenlerin öncelikle dilsel, yöntemsel ve genel-pedagojik yeterliklere sahip olmalarını beklemektedir $(2009,59)$.

Yukarıda "bir ögretmen-bir dil" ilkesi bağlamında immersion yöntemini uygulayan okul öncesi kurumlarda sürekli olarak iki görevli öğretmenin bulunduğunu ve ana dilden sorumlu eğitimci öğretmenin çocuklarla anadilinde konuşurken, diğer öğretmenin çocuklarla sadece yabancı dilde iletişime geçtiğinden söz etmiştik. Bu sistemin işleyişine göre her iki öğretmen sınıf ortamını paylaşarak sorumlu oldukları dili kullanırken eğitimci öğretmenin yabancı dili hangi seviyede bilmesi daha doğrusu bilip bilmesi tartışma konusu olmaktadır. Alan yazında kesin bir evetten kesin bir hayıra kadar görüşler bulunmakla birlikte uygulamadaki öğretmenlerin ifadelerinden de anlaşılacağı üzere eğitimci öğretmenin yabanc1 dili belirli bir sevi- 
yede bilmesi sınıf ortamındaki eğitim-öğretim sürecini farklı açılardan olumu yönde etkilemektedir. Eğitimci öğretmenlerin yabancı dili belirli bir seviyede konuşması

- Dersin niteliğinin yükselmesinde;

- Sınıf içi çalışmalara katılabilmede;

- Elde edilen verileri kendi öğretme sürecine aktarmada;

- Birlikte materyal hazırlama ve geliştirmede son derece yararlı olacağını belirtmektedir.

(Nürnberger Empfehlungen 2010)

Öğretmenlerin dilsel yeterliklerinin yanı sıra genel olarak uyguladıkları yöntemler konusunda da bilgi sahibi olmaları iki dilli yabancı dil öğretiminin başarısı bakımından son derece önemlidir. Ancak ülkemizde okul öncesi alana öğretmen yetiştiren yükseköğretim kurumlarının lisans programlarında iki dilli yabancı dil öğretimine ve yöntemlerine yönelik dersler yer almamaktadır. Dünyada erken yaşta iki dilli yabancı dil öğretilmesinin yaygın olmasına rağmen öğretmen yetiştiren programlarda erken yaşta iki dilli yabancı dil öğretim yöntemlerine yer verilmemesi bir eksiklik olarak görülmektedir. Bu konuda öncelikli çözümün okul öncesi öğretim kurumlarında görevli öğretmenlere meslek içi eğitimde bu yöntemin anlatılması, bilahare de her iki lisans programlarına erken yaşta iki dilli yabancı dil yöntemlerinin dâhil edilmesidir.

İki dili sınıf ortamlarında eğitim öğretim faaliyetlerinin sağlıklı yürütülebilmesi açısından yabancı dil öğretmenlerinin de 3-6 yaş çocuğun psikomotor- sosyal-duygusal, bilişsel alan ve öz bakım becerilerinin gelişimini destekleyecek gerekli bilgi ve becerilere sahip olması, yabancı dil öğretmenlerini sadece yardımcı öğretmen konumundan arındırıp onlara eğitimci öğretmenlerle sınıf ortamlarında eşit konuma getirecektir. Yabancı dil öğretmeni etkinlikleri, eğitim ortamlarını, yöntem ve teknikleri çocukların gereksinimlerine göre uyarlama ve düzenleme konusunda deneyimlerini eğitimci öğretmen ile paylaşabilecektir. Aşağıda aktarılan öğretmen görüşlerinde yer alan, eğitimci öğretmenin yabancı dil öğretmeni üzerinde kurduğu otorite böylelikle kendiliğinden kalkmış olacaktır.

A1 (İngilizce Öğretmeni):

Çocuklar benimle iletişime geçmek zorunda olduklarında önceleri tereddüt yaşıyorlar. Türkçe öğretmeninden yardım istiyorlar. Etkinlikler uygulanırken çocuklar genelde anadilini ve anadilini konuşan ögretmeni tercih ediyor. Etkinlikleri uygularken çocuklar ilk zamanlarda pasif oluyorlar. Mesleğe ilk başladığım zamanlarda özellikle çocukların İngilizceyi anlamadıkları ilk aşamalarda daha çok Türkçe ögretmeni aktif oluyordu. Çocuklarda sinıf içinde daha çok onu tercih ediyordu. Bende bu durumda biraz endişeye kapllyordum hatta çocukların beni sevmediklerini ya da etkinliği uygulamada başarısız olduğumu düşünebiliyordum. Bazen de kendimi bir ögrretmenden ziyade bir yardımcl gibi hissediyordum. Ancak zamanla fark ettim ki çocukların bu tercihlerinde önemli olanın ben değil, kullandı̆̆ım ĕgitim dilini anlamamalarıymış. Çocukların beni anlaması ve etkin katılması için daha çok eğlenceli etkinlikler seçmeye, resimleri, farkl işitsel ve görsel materyalleri yoğun olarak kullanmaya, beden dilimi uygulamalarda daha çok kullanmaya başladım. Aslında zamanla deneyimlerin arttıkça eğitim yöntemlerimi değiştirmeye başladım ve oluşabilecek sorunları da aşmak için farklı ve kalıcı çözümler üretmeye başladım. Ve gördüm ki ben yöntemlerimi değiştirdikçe çocukları ve ihtiyaçların analiz edebilir duruma geldim. Dolayısı ile sinıf içerisindeyken kendimi bir yardımcıdan ziyade aktif bir 
ögretmen gibi hissetmeye başladım.

A2 (İngilizce Öğretmeni):

Programı uygularken sını öğretmeninin İngilizce öğretmenine yardımcı ögretmen gibi muamele göstermemesi bence bu programdaki en büyük sorunlardan biri, sinff öğretmeni bir otorite ve bu otoritesini İngilizce ögretmenine de uyguluyor. Paslaşarak yapılması gereken etkinlikler istenildiği gibi yapılmıyor yani Ingilizce ögretmeni ders yaparken sinıf ögretmeni kendi özel islerini hallediyor ve dil etkinliği amacına ulaşamıyor

A3 (Türkçe öğretmeni):

Çocuklar ikinci dili kullanma becerileri arttıkça, günlük yaşam deneyimlerini ikinci dil ögretmeniyle de paylaşmak istiyorlar. Ingilizce de alt yapr oluştukça her iki ögretmenle de iletişim halinde oluyorlar. Ama akranlarıyla yaşadıkları çatışmalarda çözümsüz kaldıklarında anadil ögretmenini, bireysel ihtiyaçlarının giderilmesinde (yönlendirme desteğiyle de) ikinci dil ögretmenini tercih ediyorlar. Çocuklar açısından; alt yapısı, geçmiş yll deneyimi olmayan gruplar ikinci dil eğitiminin ilk aylarında özellikle pasif ve hareketsiz etkinliklerde sıkllyyorlar. Aynı şekilde deneyimli çocukların fazla sayıda olduğu gruba sonradan gelen çocuklarda da sıkılma, dikkatini toplamada güçlük, huzursuzluk çıkarma gibi durumları çocuk, ikinci dili kabul edene kadar gözlemliyorum. İkinci dil ögretmenini otorite olarak tanımama ve yok sayma davranışları da sergiliyorlar bu süreçte. Hareketli oyun, müzik etkinlikleri yoğun verildiğinde rahatliyorlar.

Öğretmenler açısındansa; iletişim kopukluğu yaşandığında (her ikisi için de ikinci dil ya da uygulama alaninda koordinasyon yetersizliği gibi sebeplerle) uygulama sirasında yanlı̧ anlama, farklı uygulama yapma gibi sorunlar yaşlyoruz.

A1 (İngilizce Öğretmeni):

Aslına bakarsanız bana göre her iki ögretmeninin de erken çocukluk pedagojine sahip olması gerekli olduğunu düşün̈̈yorum. Ĕ̆gr her iki ögretmende erken çocukluk ĕgitimi alanın da bilgi sahibi değilse özellikle sinuf yönetiminde, çocuklarla iletişim kurmada sorunlar yaşanabiliyor. Çocuğun tanınması, gelişime uygun ögretim tekniklerinin ya da stratejilerini bilmeyen ögretmen özellikle dil ögretiminde sorunlar yaşayabiliyor. Çocuğa uygun etkinlik uygulamada, çocuğu değerlendirme, çocukla etkileşim kurmada hatalar yapabiliyor. Bu durumda da çocuklar ögretmene ya da okula karşı olumsuz tutum geliştirebiliyorlar. Dolaylslyla ikinci dile karşıda olumsuz tutum geliştirme olasıllğ

A3 (Türkçe öğretmeni):

Ikinci dil ögretmenini otorite olarak tanımama ve yok sayma davranısları da sergiliyorlar bu süreçte. Hareketli oyun, müzik etkinlikleri yoğun verildiğinde rahatllyorlar.

A4 (Türkçe öğretmeni):

Sinıf içi uygulamalarında her ne kadar güne başlamadan ne zaman neler yapacă̆ımızı konuşarak etkinlikleri düzenlesek de özellikle sınıfta hiç 
Ingilizce anlamayan çocuklar olduğunda İngilizce ögretmeni zorlanıyor. $O$ zaman ben devreye girdiğimde çocuk bana bağlanıyor o çocuğu İngilizce etkinliğe katmak zor olabiliyor. Böyle durumlarda etkinliklerimizin sınıf içinde sırası değiştiğinde zaman zaman sikıntı yaşayabiliyoruz ama bir ortak nokta buluyoruz.

\section{Sonuç ve Öneriler}

Ülkemizde, uzun yıllardan beri AB dil politikalarına uyum sağlamak amacıyla önemli adımlar atılmakta, erken yaşta yabancı dil eğitimi ve çok dillilik Avrupa Birliği ülkelerinde olduğu gibi ülkemizde de önemli hedefler arasında yer almaktadır. Bununla birlikte dilbilimcilerin ve eğitim bilimcilerin ortaya koyduğu araştırmalarda da erken çocukluk dönemini dil ediniminde en duyarlı dönem olarak kabul edilmektedir. Bu nedenle özellikle Batı ülkelerinde erken yaşta yabancı dil eğitimine yönelik olarak sürekli yeni yöntemler geliştirilip okul öncesi kurumlarda başarıları yönünden denenmektedir. Çocukların dil gelişimine ve dil eğitimlerine yönelik geliştirilen bu modeller arasında özellikle "immersion yöntemi" günümüzde giderek daha yaygın bir biçimde kullanılmaktadır. Ancak "bir dil bir ögretmen" ilkesinden hareket eden bu yöntemin başarılı bir biçimde uygulanması büyük ölçüde eğitimi gerçekleştiren öğretmenlerin sahip olduğu mesleki yeterliklerle doğrudan ilişkilidir.

Ülkemizde okul öncesi alana öğretmen yetiştiren yükseköğretim kurumlarının lisans programlarında iki dilli yabancı dil eğitimine ve yöntemlerine yönelik dersler, yer almamaktadır. $\mathrm{Bu}$ immersion yöntemi için de geçerlidir.

Bu konuda öncelikli çözüm olarak okul öncesi öğretim kurumlarında görevli öğretmenlere meslek içi eğitimde iki dilli yabancı dil eğitimi yöntemlerinin tanıtılması önerilmektedir.

Uzun vadeli çözüm olarak ise gerek okul öncesi öğretmenliği lisans programlarına gerekse eğitim fakültelerinin yabancı dil öğretmeni yetiştiren Almanca, Fransızca, İngilizce lisans programlarına erken yaşta iki dilli yabancı dil eğitim yöntemlerinin dâhil edilmesi gerekli görülmektedir. Ayrıca “íki Dilli Okul Öncesi Öğretmenliği Lisans Programı'nın” açılması da gündeme alınmalıdır. 


\section{KAYNAKÇA}

Adalı O. (1998). “Anadili Olarak Türkçe Öğretimi Üzerine”. Ed. A. Kilimci, Anadilinde Çocuk Olmak: Yabancı Dilde Eğitim (1998) İstanbul.

Barnett W. S.,Yarosz D. J., Thomas J., Jung K. \& Blanco D. (2007). "Two-Way and Monolingual English Immersion in Preschool Education: An Experimental Comparison". Early Childhood Research Quarterly 22/3 (2007) 277-293.

Barrett P. M., Cooper M. \& Teoh A. B. (2014). "When Time is of the Essence: A Rationale For 'Earlier' Early Intervention". Journal of Psychological Abnormalities in Children 3/4 (2006) 133-140.

Braun V.\& Clarke V. (2006). "Using Thematic Analysis in Psychology". Qualitative Research in Psychology 3/2 (2006) 77-101.

Brewer C.\& Campbell D. G. (1991). Rhythms of Learning: Creative Tools for Developing Lifelong Skills. Chicago 1991.

Chilla S. \& Fox-Boyer A. (2012). İkidillilik/ Çokdillilik. Anne Baba El Kitabı. Çev. E. Babur. Roßdorf 2012.

Cohen A. D. \& Swain M. (1976). "Bilingual Education: "The Immersion" Model in the North American Context". TESOL Quarterly (1976) 45-53.

Chugani H. T. (1999). "Review: Metabolicimaging: A Window on Brain Development and Plasticity". The Neuroscientist 5/1 (1999) 29-40.

De Palma R. (2010). Language Use in the Two-Way Classroom: Lessons from a Spanish-English Bilingual Kindergarten. Clevedon 2010.

Dryden G. \& Vos J. $\left(2005^{3}\right)$. The New Learning Revolution. UK 2005.

Duverger J. (2005). L'Enseigenement en Classe Bilingue Teaching in Bilingual Classrooms. Paris 2005.

Fisher J. (2009). Puppets, Language and Learning. London 2009.

Hickey T. (2001). "Mixing Beginners and Native Speakers in Minority Language Immersion: Who Is Immersing Whom?" Canadian Modern Language Review 57/3 (2001) 443-474.

Europäische Kommission (1996). Weißbuch Lehren und Lernen: Auf dem Weg zur kognitiven Gesellschaft. Source: http://europa.eu/documents/comm/white_papers/pdf/com95 590_de.pdf

Genç İ. B. \& Er S. (2007). "Erken Yaşta Yabancı Dil Öğretimi Üzerine Veli ve Öğretmen Görüşleri”. Kastamonu Ĕgitim Dergisi 15/1 (2007) 21-30.

Gündoğar F. (2004). "Yeni Projeler Işs̆ğında Erken Yaşta Yabancı Dil Öğretimi”. Hasan Ali Yücel Eğitim Fakültesi Dergisi 2 (2004) 97-111.

Kersten K. (2009). "Bilinguale Kindergärten und Grundschulen: Wissenschaft und Praxis im Kieler Immersionsprojekt". Ed. P. Baron, Bilingualität im Kindergarten und in der Primarstufe. Bessere Zukunftschancen für Unsere Kinder. Opole 2005.

Source: http://www.kristinkersten.de/media/5589f76bcf778ad0ffff811dffffff1.pdf

Kommission Der Europäischen Gemeinschaften (2003). Mitteilungen der Kommission an den Rat, das Europäische Parlament, den Wirtschafts- und Sozialausschuss und den Ausschuss der Regionen. Förderung des Sprachenlernens und der Sprachenvielfalt: Aktionsplan 2004 - 2006. Source: http://www.cor.europa.eu/document/de/cdr287-2003_rev1_poj_de.pdf.

Krashen S. (1973). "Lateralization, Language Learning and Critical Period: Some New Evidence". Language Learning 23/1 (1973) 63-74.

Lake V. E. \& Pappamihiel N. E. (2003). "Effective Practices and Principles to Support English Language Learners in the Early Childhood Classroom". Childhood Education 79/4 (2003) 200-203.

Menken K. \& García O. (2010). Negotiating Language Education Policies in Schools: Educators as Policymakers. New York 2010.

Nürnberger Empfehlungen zum frühen Fremdsprachenlernen (2010). München.

Source: $h$ ttp://www.goethe.de/lhr/prj/nef/deindex.htm?wt_sc=nuernberger-empfehlungen

Ram-Tsur R., Nissim M., Zion M., Ben-Soussan T.D. \& Mevarech Z. (2013). "Language Development: The Effect of Aquatic And On-Land Motor Interventions". Creative Education 4/9 (2013) 41-50.

Schwartz M., Mor-Sommerfeld A. \& Leikin M. (2010). "Facing Bilingual Education: Kindergarten 
Teachers' Attitudes, Strategies and Challenges". Language Awareness 19/3 (2010) 187-203.

Schwartz M., Wee Koh P., XiChen B., Sinke M. \& Geva, E. (2016). "Through the lens of teachers in two bilingual programmes: a look at early bilingual education". Language, Culture and Curriculum 29/2 (2016) 141-168.

Schwartz M. \& Palviainen A. (2016). "Twenty-First-Century Preschool Bilingual Education: Facing Advantages and Challenges in Cross-Cultural Contexts". International Journal of Bilingual Education and Bilingualism 19/6 (2016) 603-613.

Senemoğlu N. (1994). “Okul Öncesi Eğitim Programı Hangi Yeterlikleri Kazandırmalıdır?”. Hacettepe Üniversitesi Ĕ̈itim Fakültesi Dergisi 10 (1994) 21-30.

Stiles J. (2000). "Neuralplasticity and Cognitive Development". Developmental Neuropsychology 18/2 (2000) 237-272.

Tekin A. K. (2016). "Attitudes of O Maniearly Childhood Preservice Teachers Toward Bilingual Early Childhood Education: Benefits, Challenges, Andsolutions". Child \&Youth Services 37/1 (2016) 7891.

Turhan B. \& Özbay Y. (2016). "Erken Çocukluk Eğitimi ve Nöroplastisite”. Erken Çocukluk Eğitimi Araştırmaları Dergisi 1/2 (2016) 46-56. Kaynak: http://ftr.hku.edu.tr/Dosyalar/21102016123805.pdf

Verein für frühe Mehrsprachigkeit an Kindertageseinrichtungen und Schulen FMKS e.V. Source: http://www.fmks-online.de/faq.html

Wode H. (1995). Lernen in der Fremdsprache: Grundzüge von Immersion und bilingualem Unterricht. Hueber 1995.

Wode H. (2004). Frühes Fremdsprachenlernen Englisch ab Kita und Grundschule. Kiel 2004.

Wode H. (2007). "Frühkindliche Mehrsprachigkeit".

Source: http://fruehkindliche-mehrsprachigkeit.de/downloads/abstracthenningwode.pdf

Yazıcı Z. \& Genç İ. B. (2008). "Okul Öncesi Dönemdeki İki dilli/ Çok dilli Çocukların Dil Kazanım Süreci”. Dil Araştırmaları Dergisi 3 (2008) 47-61.

Kaynak: http://www.dilarastirmalari.com/files/Dil_Arastirmalari_sayi03_Yazici_ilter_47_61.pdf

Yıldırım A. \& Simsek H. (1999). Sosyal Bilimlerde Nitel Araştırma Yöntemleri. Ankara 1999. 